\title{
Small mammals in a fragment and adjacent matrix in southeastern Brazil
}

\author{
Passamani, $M{ }^{\mathrm{a} *}$ and Ribeiro, $D .^{\mathrm{b}}$

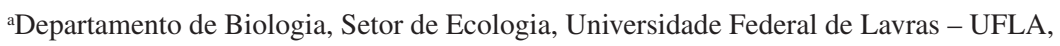 \\ CP 3037, CEP 37200-000, Lavras, MG, Brazil

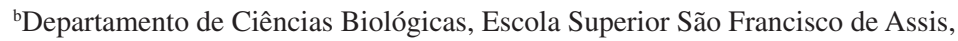 \\ Av. Bernardino Monteiro, 400, CEP 29650-000, Santa Teresa, ES, Brazil \\ *e-mail: mpassamani@ufla.br \\ Received November 14, 2007-Accepted February 25, 2008 - Distributed May 31, 2009
}

(With 1 figure)

\begin{abstract}
Between May 2002 and May 2003, we studied a small mammal community from an Atlantic forest fragment surrounded by a coffee plantation in the municipality of Santa Teresa, Espírito Santo state, Brazil. We obtained a total of 300 captures of 114 individuals belonging to 11 mammal species. Seventy three percent of the species captured in the forest also used the coffee plantation, mainly males (90\%) and young (80\%) individuals of Marmosops incanus. The exceptionally low recapture rate in the coffee plantation suggests that it functions as a corridor between fragments, rather than as a habitat for these species. Understanding the role of matrix habitat use in fragmented landscapes is an important factor in small mammal conservation, as it asymmetrically affects the rate and mode of individual movements of different species.
\end{abstract}

Keywords: Atlantic Forest, coffee plantation, landscape, fragmentation, conservation.

\section{Pequenos mamíferos em fragmentos e matriz adjacente no sudeste do Brasil}

\begin{abstract}
Resumo
Entre março de 2002 e abril de 2003, estudamos uma comunidade de pequenos mamíferos em um fragmento de Floresta Atlântica cercado por plantação de café no município de Santa Teresa, estado do Espírito Santo, Brasil. Obtivemos um total de 300 capturas de 114 indivíduos pertencentes a 11 espécies de mamíferos. Setenta e três por cento das espécies capturadas na floresta também usaram a plantação de café, principalmente indivíduos machos (90\%) e jovens $(80 \%)$ de Marmosops incanus. A taxa de recaptura excepcionalmente baixa na plantação de café sugere que este possa funcionar como um corredor entre os fragmentos, e não como habitats para as espécies. Entender como é o uso da matriz de habitats em paisagens fragmentadas é um importante fator na conservação de pequenos mamíferos, uma vez que ele afeta assimetricamente a taxa e o modo de movimento de indivíduos de diferentes espécies.
\end{abstract}

Palavras-chave: Floresta Atlântica, plantação de café, paisagem, fragmentação, conservação.

\section{Introduction}

While the effect of forest fragmentation on the abundance and richness of small mammals has been studied by several authors, consistent and generalizable effects of fragment size on these community parameters remains elusive in fragmented Neotropical forest landscapes (Malcolm, 1991; Gascon and Lovejoy, 1998; Pardini, 2004; Passamani 2003). Species richness and abundance in a forest fragment are modulated not just by fragment size, but also fragment shape, degree of isolation and connectivity (Andrén, 1994; Passamani, 2003; Pardini, 2004; Pardini et al., 2005; Ewers and Didham, 2006). There is a considerable inconsistency across the results of studies evaluating these relationships (Debinski and Holt, 2000).
Many small mammal species depend fundamentally on forest for their survival, but the deforestation of the Brazilian Atlantic Forest has severely fragmented the ecosystem - causing the extinction of several species (Viveiros de Castro and Fernandez, 2004). Other species have benefited; increasing their abundance in new created anthropogenic habitats (Fernandez et al., 1998; Fonseca and Kierulff, 1989; Feliciano et al., 2002; Laurance et al., 2002; Viveiros de Castro and Fernandez, 2004; Pardini, 2004; Umetsu, 2005). The ability to tolerate or utilize matrix habitats is frequently associated with a species' ability to persist in fragmented landscapes (Laurance, 1991). Specialist species in forest habitats without the 
ability to cross or to use the matrix often demonstrate reduced abundance in forest fragments (Gascon et al., 1999; Passamani, 2003).

The Atlantic Forest is regarded as one of the world's five most important biodiversity hotspots (Myers et al., 2000). Originally the Atlantic Forest covered almost the entire Brazilian coast, but is presently relegated to a series of small fragments (Galindo-Leal and Camara, 2003), some embedded within highly urbanized areas. One of the main consequences of the fragmentation process is the isolation of the forest remnants, but the isolation of the animal populations can be avoided through movement of some individuals among the fragments (Pires et al., 2002). The movement among forest fragments does not depend only on the characteristics of the surrounding vegetation but also on the biological attributes and behavior of the species involved (Passamani, 2003; Dayle et al., 2003; Pires et.al., 2002; Ewers and Didham, 2006). If a species is incapable of moving across the areas surrounding a fragment, they are restricted to a small and isolated portion of the total area (Kozakiewicz, 1993), which can generate local extinctions.

The main goal of this study was to evaluate which small mammal species were able to utilize a matrix habitat of coffee plantation.

\section{Materials and Methods}

The study was carried out in the municipality of Santa Teresa, in the state of Espírito Santo, Brazil $\left(19^{\circ} 58^{\prime} \mathrm{S}\right.$; and $\left.40^{\circ} 35^{\prime} \mathrm{W}\right)$, which has native vegetation of the Atlantic Forest.

The fragment sampled has approximately 7.6 ha of secondary and mature forest with many epiphytes and liana, and a very thick sub-canopy at ca $20 \mathrm{~m}$. This fragment is surrounded by a coffee plantation and other forest fragments, at distances between 100 and $300 \mathrm{~m}$ (Passamani, 2003).

We surveyed small mammals in two distinct areas: in the interior of the forest fragment and in the neighboring coffee plantation (approximately four years old) over five consecutive nights every month from May 2002 to May 2003. The forest was sampled with three parallel transects set $50 \mathrm{~m}$ apart and 5 capture point at $15 \mathrm{~m}$ intervals in each transect, sampling a 0.6 ha of area. At each point we placed one trap on the ground (lower strata) and another in tree branches at one to two meters above the ground (middle strata) $(n=30)$. In the coffee plantation, we placed five parallel transects, $25 \mathrm{~m}$ apart, that extended from the border of the fragment toward the coffee plantation, sampling a total area of 0.6 ha too. We placed five traps in each transect at $15 \mathrm{~m}$ intervals $(\mathrm{n}=25)$. Large $(42 \times 21 \times 21 \mathrm{~cm})$ and medium $(30 \times 10 \times 10 \mathrm{~cm})$ Sherman and wire mesh traps baited with banana and codfish oil were used in both locations. Captured individuals were identified and marked with numbered ears-tags for identification. Only marsupials were classified by sex, reproductive condition and age accord- ing to Tyndale-Biscoe and Mackenzie (1976). Vouchers specimens were added to the collection of the Museu de Biologia Prof. Mello Leitão, Santa Teresa, ES.

Capture success rate was calculated by multiplying the total number of individuals captured by 100 and dividing the results by the capture effort (number of trap nights). In both areas we used a Spearman correlation to verify the relationship between the abundance of species and the $\chi^{2}$ test (Yates correction) to verify differences in sexual ratio and age (Zar, 1984).

\section{Results}

With a capture effort of 3575 traps/nights, eleven species of small mammals were captured (Table 1). A total of 114 individuals were captured in 300 capture events (Table 1), corresponding a capture success of $8.33 \%$. A porcupine (Sphiggurus insidiosus Lichtenstein, 1818) individual captured in the coffee plantation was excluded from analysis.

In the forest fragment, 99 individuals were captured 271 times across 1950 trap/nights, corresponding to a capture success rate of approximately 14\% (Table 1). Marmosops incanus Lund (1840) was the most abundant species, accounting for approximately $36 \%$ of total captures (Figure 1).

In the coffee plantation area, a capture effort of 1625 traps/nights resulted in 29 captures, (capture success rate ca 2\%) (Table 1). Marmosops incanus and Oligoryzomys nigripes Olfers 1818 were the most abundant species captured, representing $33.3 \%$ and $25 \%$ of the total captures. Other species captured were Guerlinguetus aestuans Linnaeus 1766, Rhipidomys mastacalis Lund 1840, Micoureus paraguayanus Tate 1831, Didelphis aurita Wied-Neuwied 1826, Euryoryzomys russatus Wagner, 1848 and Gracilinanus microtarsus Wagner 1842 , together accounting for less than $30 \%$ of the total number of individuals (Figure 1). Among the $M$. incanus specimens captured in the coffee plantation, only one was recaptured.

Despite the fact that $M$. incanus had been the most abundant species in both the coffee plantation and the forest, the abundance of this species was uncorrelated between the two areas (Spearman, $r=-0.06$; $p=0.85$ ). Species captured both in the forest and the coffee plantation included M. incanus, G. aestuans, M. paraguayanus, D. aurita, G. microtarsus, R. mastacalis, E. russatus and $O$. nigritus (corresponding to $73 \%$ of the species). The exceptions were Nectomys squamipes Brants 1827, Philander frenatus Olfers 1818 and Callithrix geoffroyi Geoffroy in Humboldt 1812. Only one individual O. nigritus was captured in the forest fragment, while six were captured in the coffee plantation.

There was no significant difference in the relative abundance of males and females of M. incanus in the forest fragment (59\% males versus $41 \%$ females; $\left.\chi^{2}=1.29 ; \mathrm{p}=0.256\right)$. The percentage of young and sub-adult individuals captured in the forest area was 
Table 1. Number of captures of small mammals in a forest and coffee plantation in southeastern Brazil, including capture effort and success.

\begin{tabular}{llll}
\hline \multicolumn{1}{c}{ Species } & Forest & Coffee plantation & Total \\
\hline DIDELPHIMORPHIA & $14(4)$ & $1(1)$ & $15(4)$ \\
Didelphis aurita & $30(11)$ & $1(1)$ & $31(11)$ \\
Gracilinanus microtarsus & $140(36)$ & $13(8)$ & $153(40)$ \\
Marmosops incanus & $12(3)$ & $1(1)$ & $13(3)$ \\
Micoureus paraguayanus & $5(3)$ & -- & $5(3)$ \\
Philander frenatus & & -- & $5(4)$ \\
PRIMATES & $5(4)$ & & $45(21)$ \\
Callithrix geoffroyi & & -- & $4(4)$ \\
RODENTIA & $45(21)$ & $1(1)$ & $7(7)$ \\
Nectomys squamipes & $3(3)$ & $6(6)$ & $4(4)$ \\
Euryoryzomys russatus & $1(1)$ & $2(2)$ & $17(12)$ \\
Oligoryzomys nigripes & $2(2)$ & $3(3)$ & $300(114)$ \\
Rhipidomys mastacalis & $14(11)$ & $29(24)$ & 3575 \\
$\quad$ Guerlinguetus aestuans & $271(99)$ & 1625 & 8.33 \\
\hline Total of captures & 1950 & 1.78 & \\
\hline Capture effort & 13.79 & & \\
\hline Capture success (\%) & & & \\
\hline
\end{tabular}

The number in brackets refers to the number of individuals captured.

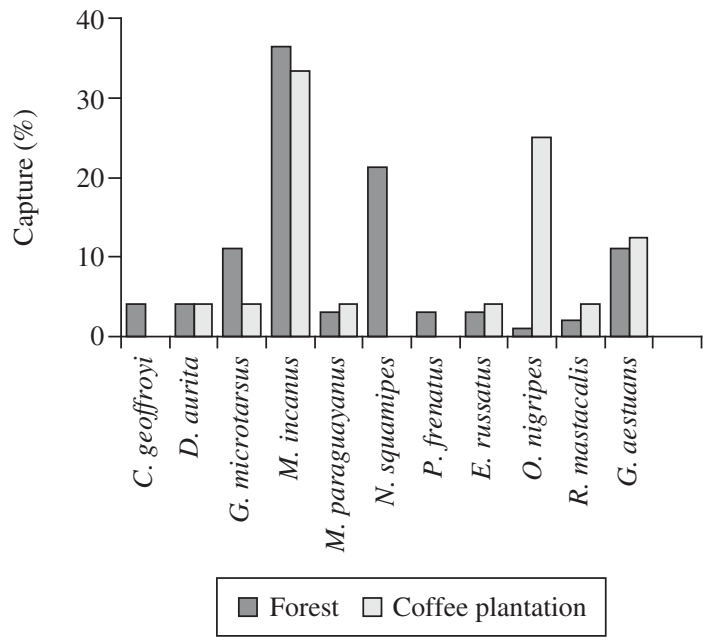

Figure 1. Capture frequency (\%) of species in the forest and the coffee plantation in southeastern Brazil

$42.6 \%$, with non-significant difference (Chi square, $\left.\chi^{2}=0.72 ; \mathrm{p}=0.395\right)$.

In the coffee plantation, the sex ratio of $\mathrm{M}$. incanus differed significantly $\left(c^{2}=34.06 ; p=0.001\right)$ being $90 \%$ males versus $10 \%$ females. The differences in individuals' ages were also significantly in the coffee plantation $\left(c^{2}=18.48 ; p=0.001\right)$, being $80 \%$ young and subadult versus $20 \%$ adult. The capture of young and subadult marsupials in the coffee plantation occurred from January to June 2003.

\section{Discussion}

The fact that some species were only captured in the forest fragment does not necessarily mean they do not use the coffee plantation for shelter or passage. Nectomys squamipes, for example, is a semi-aquatic species extremely well adapted to live in surrounding rivers and creeks (Ernest and Mares, 1986; Emmons and Feer, 1997) and it was not captured in the coffee plantation area probably because the traps had not been set near water. Among other species, a P. frenatus individual was followed by radio-tracking in these areas and it used both the forest and the coffee plantation for daytime shelter and passage, and a group of C. geoffroyi was also followed by radio and used both areas for passage too (Passamani unpub. data). Thus, it is possible that many species captured in the forest fragment may have some ability to exploit the coffee plantation. This ability may explain why many species persist in that fragment of the area, since it is possible for individuals to migrate from one fragment to another (Passamani, 2003), as verified in other studies in the Atlantic Forest (Pires and Fernandez, 1999; Pires et al. 2002).

The capacity to occupy the matrix seems to be a good parameter to foresee the vulnerability of the species to fragmentation (Umetsu, 2005), since isolated populations in the small habitat remnants can be subject to higher risk of extinction (Wilcox and Murphy, 1985; Viveiros de Castro and Fernandez, 2004). In this study, the majority of the small mammal species use the coffee plantation, and the proximity of the forest fragments 
$(<400 \mathrm{~m})$ can explain the facility of occupation of this matrix, since individuals were often detected moving among these fragments and crossing the coffee plantation (Passamani, 2003).

The occurrence of $G$. aestuans in the coffee plantation was likely a result of the presence of Attalea sp. (Arecacae), one of their major sources of food (Souza, 2000), as most captures were made in areas close to that palm tree. In Costa Rica, some species, like squirrels, captured in coffee plantations may have been foraging rather than simply in transit between forest remnants (Dayle et al., 2003). The capture of Sphiggurus insidiosus in the coffee plantation was unusual, considering that it is a species that dwells in trees and is difficult to capture in traps. An individual of this species, however, was radio-tracked and used both the forest and the coffee plantation for daytime shelter and passage (Passamani unpub. data).

Except for $O$. nigripes, all species captured in the coffee plantation were more abundant in the forest fragment. Similar results were reported by Passamani (2003) and Viveiros de Castro and Fernandez (2004) for the Atlantic Forest, and by Malcolm (1991), Laurance and Bierregaard (1997) and Gascon et al. (1999), for Amazonian forest fragments, where small mammal communities that use the vegetation surrounding forest fragments are similar to those found within the fragments themselves, probably because of an intense edge effect.

The great majority of the marsupial specimens captured in the coffee plantation were male $(90 \%)$. Among these, about $78 \%$ were sub-adult or young individuals who were captured mainly between January and April (2003), when the rainy season ends and the dry season begins, and food availability (fruit and insects) tends to decrease (Charles-Dominique, 1983; Stalling, 1989). This fact might be related to an increase in competition and agonistic interaction among individuals within the forest fragment (Passamani, 2003). Thus, it is probable that those individuals that use the coffee plantation area had lost their territory in the competition against older individuals in the forest, and moved into human-altered areas looking for other forest remnants to settle, or they are in the process of dispersion. The combination of the very small number of individuals recaptured and the unique capture of only sub-adult or young individuals in the coffee plantation supports the conjecture that these animals may be born in the forest fragment and later migrate to the coffee plantation.

Malcolm (1991) carried out a quantitative study of the effects of forest fragment size and isolation on mammal communities in the Amazon Forest. He concluded that fragmentation of the forest results in continuous alterations in diversity, abundance and biomass of small mammals, with a decrease in species diversity and increase in abundance of those species that utilize forest fragment edges. Small mammal richness may also increase or not suffer meaningful change with fragmentation because many times the species are associated with the matrix areas surrounding the fragments (Paglia et al., 1995; Gascon et al., 1999; Passamani, 2003; Pardini, 2004). The use of the matrix can explain the variation in responses to habitat fragmentation (Laurance, 1991; Malcolm, 1991; Gascon et al., 1999; Pardini, 2004) and is critical in the dynamics and composition of small mammal communities in tropical forest remnants. As a consequence, understanding patterns of matrix use can provide empirical support for conservation and management strategies of fragmented landscapes.

It is important to mention that in our study sites, $M$. incanus is the most abundant species, but as no individuals were recaptured in the coffee plantation it remains unknown if $M$. incanus actually resides there. Marmosops incanus probably uses the coffee plantation to move between forest patches, permitting them to reach high abundances in some small forest patches (Passamani, 2003). In Costa Rica, mature coffee shrubs appear to provide cover and facilitate movements, connecting mammal populations into larger metapopulations and reducing local extinction (Dayle et al., 2003). As observed by Silva et al. (2005), the maintenance of small forest patches in close proximity is fundamental for the conservation of small mammals inhabiting agricultural landscapes in Canada, and the responses of some species will change as the surrounding landscape matrix is transformed (Lindenmayer et al., 2001). Hence, the type of vegetation that constitutes the surround of forest fragments in an Atlantic Forest is an important factor that influences the population dynamics of many species of small mammals, and the coffee plantation is permeable to the movement of them among fragments. This information can support our understanding of Neotropical fauna as well as conservation and management strategies within this biodiversity hotspot.

Acknowledgements - We would like to thank the Museu de Biologia Prof. Mello Leitão (MBML) for the support, the Instituto Nacional de Meteorologia (INMET) for the climatic data, and the IBAMA for the specimen collection permits. We thank the people who helped us during the fieldwork, especially Jenilson Dalmaschio and Roberto B. Narciso. Elizabeth Nichols, Adriano G. Chiarello and Renato Gregorin made invaluable comments in the earlier versions of this manuscript and two anonymous referees provided some suggestions for improving this manuscript. Finally, thanks to Luiz João da Silva for aid with english language.

\section{References}

ANDRÉN, H., 1994. Effects of habitat fragmentation on birds and mammals in landscapes with different proportions of suitable habitat: a review. Oikos, vol. 71, no. 3, p. 355-366.

CHARLES-DOMINIQUE, P., 1983. Ecology and social adaptations of didelphid marsupials: comparison with eutherians of similar ecology. In EISENBERG, JF. and KLEIMAN, D. (Eds.). Advances in the study of mammalian behaviour. Shippensburg, Pennsylvania: The American Society of Mammalogist. p. 395-422. Special Publication. 
DAYLE, GC., CEBALLOS, G., PACHECO, J., SUZÁN, G. and SÁNCHEZ-AZOFEIFA, A., 2003. Countryside bigeography of Neotropical Mammals: Conservation opportunities in agricultural landscapes of Costa Rica. Conservation Biology, vol. 17, no. 6, p. $1814-1826$.

DEBINSKI, DM. and HOLT, RD., 2000. A survey and overview of habitat fragmentation experiments. Conservation Biology, vol. 14 , no. 2 , p. 342-355.

EMMONS, L. and FERR, F., 1997. Neotropical rainforest mammals: a field guide. Chicago: The University of Chicago Press.

ERNEST K, A. and MARES, MA., 1986. Ecology of Nectomys squamipes, the neotropical water-rat in Central Brazil: Home range, habitat selection, reproduction and Behavior. Journal of Zoology, vol. 210, no. 4, p. 599-612.

EWERS, RM. and DIDHAM, RK., 2006. Confounding factors in the detection of species responses to habitat fragmentation. Biological Review, vol. 81, no. 1, p. 117-142.

FELICIANO, BR., FERNANDEZ, FAS., FREITAS, D. and FIGUEIREDO, MSL., 2002. Population dynamics of small rodents in a grassland between fragments of Atlantic Forest in southeastern Brazil. Mammalian Biology, vol. 67, no. 5, p. 304-314.

FONSECA, GAB. and KIERULFF, MCM., 1989. Biology and natural history of Brazilian Atlantic Forest small mammals. Bulletin Florida State Museum Biological Science, vol. 34, no. 1, p. 99-152.

GALINDO-LEAL, C. and CÂMARA, IG., 2003. The Atlantic Forest of South America: biodiversity status, threats and outlook. Washington: Center for Applied Biodiversity Science and Island Press.

GASCON, C. and LOVEJOY, TE., 1998. Ecological impacts of forest fragmentation in central Amazonia. Zoology, vol. 101, no. 4, p. 273-280.

GASCON, C., LOVEJOY, TE., BIERREGAARD, RO., MALCOLM, JR., STOUFFER, PC., VASCONCELOS, HL., LAURANCE, WF., ZIMMERMAN, B., TOCHER, M. and BORGES, S., 1999. Matrix habitat and species richness in tropical Forest remnants. Biological Conservation, vol. 91, no. 2-3, p. 223-229.

KOZAKIEWICZ, M., 1993. Habitat isolation and ecological barriers: the effect on small mammal populations and communities. Acta Theoriologica, vol. 38, no. 1, p. 1-30.

LAURANCE, WF., 1991. Ecological correlates of extinction proneness in Australian tropical rainforest mammals. Conservation Biology, vol. 5, no. 1, p. 79-89.

LAURANCE, WF. and BIERREGAARD, RO., 1997. Tropical forest remnants: ecology, management, and conservation of fragmented communities. Chicago: The University of Chicago Press.

LAURANCE, WF., LOVEJOY, T., VASCONCELOS, HL., BRUNA, EM., DIDHAN, RK., STOUFFER, PC., GASCON, C., BIERREGAARD, RO., LAURANCE, SG. and SAMPAIO, E., 2002. Ecossystem decay of Amazonian forest fragments: a 22 year investigation. Conservation Biology, vol. 16, no. 3, p. 605-618.

LINDENMAYER, DB., CUNNINGHAMB, RB., MACGREGOR, C., TRIBOLET, C. and DONNELLY, CF., 2001. A prospective longitudinal study of landscape matrix effects on fauna in woodland remnants: experimental design and baseline data. Biological Conservation, vol. 101, no. 2, p. 157-169.

MALCOLM, JR., 1991. The small mammals of Amazonian forest fragments: pattern and process. Gainsville: University of Florida. Tese de Doutorado.

MYERS, N., MITTERMEIER, RA., FONSECA, GAB. and KENT, J., 2000. Biodiversity hotspots for conservation priorities. Nature, vol. 403, no. 6772, p. 853-858.

PAGLIA, AP., De MARCO Jr., P., COSTA, FM., PEREIRA, RF. and LESSA, G., 1995. Heterogeneidade estrutural e diversidade de pequenos mamíferos em um fragmento de mata secundária em Minas Gerais, Brasil. Revista Brasileira de Zoologia, vol. 12, no. 1, p. 67-79.

PARDINI, R., 2004. Effects of forest fragmentation on small mammals in an Atlantic Forest landscape. Biodiversity and Conservation, vol. 13, no. 13, p. 2567-2586.

PARDINI, R., De SOUZA, SM., BRAGA-NETO, R. and METZGER, JP., 2005. The role of Forest structure, fragment size and corridors in maintaining small mammals abundance and diversity in an Atlantic Forest landscape. Biological Conservation, vol. 124, no. 2, p. 253-266

PASSAMANI, M., 2003. O Efeito da Fragmentação da Mata Atlântica Serrana sobre a comunidade de Pequenos Mamíferos de Santa Teresa, Espírito Santo. Rio de Janeiro: Universidade Federal do Rio de Janeiro. Tese de Doutorado.

PIRES, AS. and FERNANDEZ, FAS., 1999. Use of space by the marsupial Micoureus demerarae in small Atlantic Forest fragments in South-eastern Brazil. Journal of Tropical Ecology, vol. 15 , no. 3, p. 279-290.

PIRES, AS., LIRA, PK., FERNANDEZ, FAS., SCHITTINI, GM. and OLIVEIRA, LC., 2002. Frequency of movements of small mammals among Atlantic Costal Forest fragments in Brazil. Biological Conservation, vol. 108, no. 2, p. 229-237.

SILVA, M., HARTLING, L. and OPPS, SB., 2005. Small mammals in agricultural landscapes of Prince Edward Island (Canada): Effects of habitat characteristics at three different spatial scales. Biological Conservation, vol. 126, no. 4, p. 556-568

SOUZA, FL., 2000. Palm nut handling behavior by squirrels. Ciência e Cultura, vol. 52, no. 3, p. 188-190.

STALLINGS, JR., 1989. Small mammals inventories in an eastern brazilian park. Bulletin of Florida State Museum, vol. 34, no. 1, p. $153-200$.

TYNDALE-BISCOE, CM. and MACKENZIE, RB., 1976. Reproduction in Didelphis marsupialis and D. albiventris in Colombia. Journal of Mammalogy, vol. 57, no. 2, p. 249-265.

UMETSU, F., 2005. Pequenos mamíferos em um mosaico de habitats remanescentes e antropogênicos: qualidade da matriz $\mathrm{e}$ conectividade em uma paisagem fragmentada de Mata Atlântica. São Paulo: Universidade de São Paulo. Dissertação de Mestrado.

VIVEIROS De CASTRO, EB. and FERNANDEZ, FAS., 2004. Determinants of differential extinction vulnerabilities of small mammals in Atlantic Forest fragments in Brazil. Biological Conservation, vol. 119, no. 1, p. 73-80.

WILCOX, BA. and MURPHY, DD., 1985. Conservation strategy: effects of fragmentation on extinction. American Naturalist, vol. 125 , no. 6, p. 879-887.

ZAR, JH., 1984. Bioestatistical analysis. 3 ed. Englewood Cliffs: Prentice-Hall. 
